\title{
FINANCING BY ASSIGNMENT OF GOVERNMENT CONTRACTS: EXPANDING THE ASSIGNEE'S RISK*
}

ON the eve of World War II, when a large part of the nation's resources were mobilized rapidly, ${ }^{1}$ many new and small businesses needed to borrow working capital in order to produce for the government. The Assignment of Claims Act of $1940^{2}$ was passed to permit these businesses to assign their government contracts as security for loans. ${ }^{3}$ Prior to the Act's passage, assignment of Government contracts was prohibited by statute. ${ }^{4}$ The Act reversed this legislative policy. In addition, it provided for protection of the assignee against certain claims which might arise between the Government and the assignor by permitting the inclusion of a clause in Navy, Army and Air Force contracts to prohibit set-offs or reduction of payments to the assignee for "any indebtedness of the assignor arising independently of such contract."'s

* Comp. Gen. Dec. B-72929 (May 18, 1950), photostatic copy on file in Yale Law Library; 18 U.S.L.WEEK 2530 (1950).

1. Government expenditures during the war amounted to roughly half of the gross national product. U.S. Dept. of Commerce, Survey of CurRent Business (Supp., July 1947). In 1949, prior to the contemporary remobilization activity, the figure was about one quarter. Mid-Year Economic Report of the President (Appendix A, July 1949).

2. 54 Stat. 1029 (1940), 31 U.S.C. \$203, 41 U.S.C. $\$ 15$ (1946). The statute limits assignment in several ways: (1) the amount of the payments to be made on the contract must aggregate at least $\$ 1,000$; (2) the assignee must be a "financial institution"; (3) the terms of a contract may forbid assignment; and (4) partial and successive assignments are prohibited unless expressly permitted in the original contract.

3. "This bill opens the door of opportunity for small business concerns to bid on these government contracts. . . . It will put idle money to work and give the little man a chance." \$6 CoNG. Rec. 13122 (1940).

4. The policy was apparently to protect the Government against the nuisance of divided and disputed claims. It was first crystallized in legislation in 1875. REv. Stat. 3477,3737 (1875), 31 U.S.C. $\$ 203,41$ U.S.C. $\$ 15$ (1946). The Government may waive the statutory objection and recognize the assignee. McGowan v. Parish, 237 U.S. 285 (1915); Nutt v. Knut, 200 U.S. 12 (1905).

The only prior use of assignments to facilitate private financing of Government contracts was during the depression. One of the measures taken to encourage production and thereby increase employment was statutory approval of assignment of W.P.A. contracts. See 48 StaT. 205 (1933), 40 U.S.C. $\$ 407$ (1934).

5. "Any contract entered into by the Department of the Army, the Department of the Air Force, or the Navy Department may provide that payments to an assignee of such contract shall not be subject to reduction or set-off and if so provided such payments shall not be subject to a reduction or set-off for any indebtedness of the assignor to the United States arising independently of the contract designated in the assignment." 54 STAT. 1029 (1940), 41 U.S.C. $\$ 15$ (1946), as amended, 31 U.S.C.A. \$ 203 (Supp. 1950).

The provision was embodied in an amendment to the proposed statute introduced by Senator Barkley during debate. 86 CoNG. REc. 12803 (1940). In proposing the amendment, Mr. Barkley stated: "A bank would not lend money on such a contract, even though it were assigned to it, if it were laboring under the fear that when the work was over and they got ready to collect their money from the contractor [sic] the government could come in and 
Such a clause was included in a contract ${ }^{6}$ made by the Navy Department with the Graham Ship Repair Company by which Graham contracted to repair naval vessels on a cost reimbursement basis. Graham assigned the contract to the Central Bank of Oakland, and Central filed notice with the Government as required by the Act. ${ }^{7}$ Later, Graham failed to pay employees' withholding taxes and unemployment taxes on wages earned in the performance of the contract. This tax debt was deducted from the amount due the assignee bank under the final payment voucher. ${ }^{8}$ The Comptroller General affirmed the validity of the deduction. ${ }^{9}$ The tax debt, he held, had not arisen "independently of the contract" because the contract on its face contemplated the payment of wages, and thereby the payment of taxes on those wages. ${ }^{10}$

In effect, this decision appears to take the position that the assignee takes the risk of non-payment of any Government claim against the assignor which the assignee can predict. This may logically extend beyond withholding and unemployment tax deficiencies. For example, under any costplus contract, the assignee can predict that the contractor-assignor will make a profit, owe federal income tax on that profit, and may default on the tax liability thus incurred. Similarily, renegotiation claims ${ }^{11}$ and crimi-

assert a claim against the contractor which had no relationship whatever to the contract and the defense program." Ibid. Cf. 20 DEc. Comp. GEN. 424 (1941) (holding that the word "indebtedness" in the statutory clause included taxes, since permitting deduction of tax claims despite the clause "undoubtedly would have the effect of seriously interfering with the object which the provision in respect to set-off was intended to accomplish").

6. The contract is identified as NObs 10230. It was executed on December 30, 1944.

7. "4. That in the event of any such assignment, the Assignee thereof shall file written notice of the assignment together with a true copy of the instrument of assignment with: a) the General Accounting Office, b) the contracting officer or the head of his department or agency, c) the surety or sureties upon the bond or bonds, if any, in connection with such contract and d) the disbursing officer, if any, designated in such contract to make payments." 54 STAT. 1029 (1940), 31 U.S.C. \$ 203, 41 U.S.C. \$ 15 (1946).

8. The Graham Company owed $\$ 453,469.55$ in withholding taxes and $\$ 11,462.91$ in federal unemployment taxes. At the time of the final voucher, $\$ 110,966.08$ was due under the contract.

9. CoMp. Gen. Dec. B-72929 (May 18, 1950), photostatic copy on file in Yale Law Library; 18 U.S.L.WEek 2530 (1950). A similar decision was made by the Comptroller General on September 11, 1950. CoMP. GEN. DEc. B-95362; 19 U.S.L. WEEK 2127 (1950). See also Rhode Island Discount Co. v. United States, 94 F. Supp. 669 (Ct. Cl. 1951).

10. "[N]o obligations under the pertinent tax statutes can arise until wages are paid, and the specific obligations here involved did not arise until wages were paid for the performance of service under the instant contract. Thus, the present indebtedness owes its very existence to the performance of work under the assigned contract, and but for that contract such debt would never have arisen.

“. . . It must have been apparent, also, that the stipulated contract compensation for direct labor hours were fixed in consideration of the payment of the contractor of the taxes involved." CoMp. GEN. DEc. B-72929, p. 4 (May 18, 1950), supra note 9.

11. See 56 STAT. 245 (1942), as amended, 50 U.S.C. $\$ 1191$ (1946). A revised act is pending. H.R. 1724, 82nd Cong., 1st Sess. (1951). See note 24 infra.

Comp. Gen. Dec. B-99808 (Dec. 26, 1950), 19 U.S.L.Weer 2294 (1951), stated that the 
nal fines or other penalties arising from defrauding the Government ${ }^{12}$ are potential liabilities, the possibility of which may be foreseen from the face of the contract. Under the Comptroller-General's rationale, the assignee must take the risk that the assignor may default on such obligations. ${ }^{13}$

This interpretation of the "no reduction" clause may severely limit assignment financing of Government contracts. If the risk of defaults such as Graham's is imposed on the assignee in addition to the risks presently peculiar to Government contracts because of their repricing and termination provisions, ${ }^{14}$ lending institutions may find Government assignments unprofitable. Protection against the risk would require supervision of the assignor's accounting and payment system. ${ }^{15}$ Where the assignor's entire

question as to the government's right of set-off of renegotiation claims against assignees had not been the subject of a decision. Since there had been some fear that an earlier deci- . sion allowing deductions for amounts due to repricing, CoMp. GeN. Dec. B-84138 (May 17, 1949), would be extended to renegotiation claims, the Comptroller General explained that the repricing decision was restricted to the factual situation presented.

12. See, e.g., 62 StaT. 749 (1948), 18 U.S.C.A. § 1001 (1950).

13. The assignee would, of course, have a claim over against his assignor. The actual value of the claim, however, would probably be slight, since the assignor would presumably have been in an extremely unstable financial position to have defaulted in the first place. Cf. Rhode Island Discount Co. v. United States, 94 F. Supp. 669 (Ct. Cl. 1951).

When the assignor is in an unstable financial condition, an additional reason for putting the risk of non-payment on the Government is that it is in a much better position to collect. If the assignor becomes a bankrupt, the Government's claim will constitute a prior lien on his assets. 52 STAt. 874 (1938), as amended 11 U.S.C.A. $\$ 104$ (Supp. 1950). An assignee bank, on the other hand, would be merely an unsecured creditor.

14. See 58 StAT. 92 (1944), 50 U.S.C. $\$ 1191$, \$1192 (Appendix 1946). Repricing differs from renegotiation in that it is applied only to protect the Government against "unreasonable or unfair" prices on a single specific contract. Renegotiation, on the other hand, is designed to eliminate excessive profits from the total income of the contractor, regardless of a small profit, or even a loss, or any particular contract. See note 11 supra.

The Graham contract contained the usual termination clause by which the Navy may terminate the contract if performance is unsatisfactory.

15. A bank's usual credit check of a prospective assignor should, of course, reveal any current tax liabilities which might affect the original decision to take an assignment. See Granger, Ghosts of Unpaid Taxes, BANkING 51, 119 (July, 1950). The problem raised by the Graham case, however, relates solely to tax indebtedness arising subsequent to the assignment. Here even a meticulous check before each advance of credit would not be enough. Refusal to make further advances upon discovery of non-payment would probably force the contractor to cease work before completion of the contract, and thereby reduce the bank's claim against the Government. In order to avoid this, the bank must do more than uncover non-payment; it must see to it that taxes are paid as they fall due.

As a matter of policy, the Navy Department would exercise its power of termination if the contractor failed to comply with the tax laws. To escape such termination, Graham perpetrated a successful fraud on the Department. "The contractor (Graham Ship Repair Co.) when challenged by the Navy Department as to the payment of taxes, presented a check punched and cancelled by the Collector of Internal Revenue in the amount of $\$ 350,000.00$. The contractor stated to the Navy Department that this check was his receipt for payment of taxes then due the Collector of Internal Revenue. This check was never presented to the Collector of Internal Revenue. It did, however, represent a considerable effort on the part of the contractor to deceive the Navy Department and had the effect of 
production is relegated to one government contract, policing might be relatively simple. The bank could have itself designated depositary ${ }^{16}$ for withholding taxes, and then hold in a trust account a portion of its periodic advances to the assignor sufficient to cover the estimated tax liability. But in the more usual case, where other contracts or non-Government work are also involved, the accounting difficulties in allocating tax to a particular contract would be almost unsurmountable. In either case, the process would be expensive to the bank, and therefore, to the assignor.

Rather than undertake such an aggressive role, it is probable that banks will change their lending policy..$^{17}$ They may decrease drastically the amount they are willing to advance on an assigned contract and thus shorten the shoestring on which the small contractor works. Or, banks may simply refuse to give loans to unknown or shaky concerns. This would increase the demand for guarantees from the agencies under the Federal Reserve Board, ${ }^{18}$ and thus, to the extent that the guarantee system met that demand, enhance the risk to the Government and the cost to the contractor.

The "no reduction" clause can be interpreted so as to avoid these results. At common law, the obligor on an assigned contract can set off against the assignee's claim obligations of the assignor arising subsequent to notice of the assignment only if they are part of the same transaction. ${ }^{19}$ The statutory

continuing the job orders from the Navy." Comp. GEN. Dec. B-72929 (May 18, 1950), supra note 9 at 2.

16. See U.S. Treas. Reg. 116, $\$ 405.606$ (1949).

17. It has been reported that banks are refusing to accept assignments. The American Banker, October 19, 1950; id. March 2, 1951. N.Y. Times, April 1, 1951, F, p. 1. ("Amendment of the statutes affecting the so-called ' $V$ ' loans for defense production, now being considered by Congress, is certain to release a flood of these essential credits, according to banking sources. Already, a vast aggregate of such loan applications is on file with banks, awaiting clarification of the situation ...").

18. The Defense Production Act of 1950, Pub. L. No. 774, 81st Cong., 2d Sess. (Sept. 8, 1950), provides for loan guarantees under certain circumstances to help borrowers who cannot otherwise obtain loans because of inability to furnish adequate security. The President is empowered to authorize defense procurement agencies ". . . to guarantee . . . any . . . financing agencies . . . against loss of principal or interest on any loan . . . made for the purpose of financing any contractor ... in connection with the performance . . of any contract . . . for the procurement of services for the national defense."

Regulations have been issued by the Federal Reserve Bank under this Act and Executive Order No. 10,161 §302(c), 15 FED. REG. 6105 (1950), setting up a loan guarantee program similar to that used during World War II, Federal Reserve Board Regulation V, 15 FED. REG. 6630 (1950). When a contractor is unable to get a loan by assigning his government contract, he may request that a financial institution apply to the Federal Reserve Bank for a guarantee of the loan. Whether such guarantees are requested by the banks and loans made on the strength of them to small businessmen depends on terms of the guarantee agreement, including how much of the loan is covered by the guarantee. World War II guarantees were for $50 \%$ to $90 \%$ of the loaned amount. For discussion of the regulations, see Emerson, Federal Guarantee of Business Loans, 64 HARv. L. Rev. 615 (1951).

19. E.g., Blog v. Burden Co., 238 App. Div. 634, 265 N.Y.Supp. 81 (2d Dep't 1933). See 4 Corbin, Contracts $\$ \$ 896-7$ (1951); 2 Williston, Contracts $\$ 433$ (1936). The rule has been honored by the Comptroller General under the Assignment of Claims Act. 
clause merely extends this rule to prior claims. As to subsequent claims such as those involved in the Graham case, ${ }^{20}$ the clause should be interpreted to treat the Government exactly as if it were a private party. ${ }^{21}$ Reductions should be restricted to those claims which a private obligor could normally assert against an assignee: failure of consideration, breach of warranty, unsatisfactory work, and the like. ${ }^{22}$ Claims such as taxes, which accrue to the Government because it is the Government rather than because it is a contracting party, should be excluded under this test as "independent of the contract." 23

The need for such an interpretation has already given rise to pressure for legislative revision of the Assignment of Claims Act to prohibit reduction of assignees' claims by tax and like indebtedness owed the Government

See 20 DEc. Comp. GEN. 458,459 (1941), in which the Comptroller-General stated: "While an assignee . . . takes the assignment subject to any existing right of set-off, his rights under the assignment are not affected by independent claims subsequently accruing in favor of the Government against his assignor. That is to say, a debtor cannot set-off rights acquired under other transactions subsequent to the date of receipt of notice of a valid assignment. [Citing cases.]" The contracts under consideration in that opinion did not contain the "no reduction" clause.

20. Notice of assignment was filed January 31,1945 . The tax debt was incurred during 1945 and 1946.

21. See United States v. Standard Rice Co., 323 U.S. 106, 111 (1944) ("in general, the United States as a contractor must be treated as other contractors under analogous situations"). Cf. Horowitz v. United States, 267 U.S. 458 (1924) (United States sued as vendee of silk, held not liable for obstruction to the performance of the contract resulting from its general embargo on shipments of silk).

22. Reductions of this type are known as "recoupment." See Waterman, SET-ofF 480-484 (2d ed. 1872); Clark, Code Pleading 633-5 (2d ed. 1947). See, generally, Clark and Surback, The Pleading of Counterclaims, 37 YALE L.J. 300 (1927). The policy of allowing recoupment of defaults occurring after notice of assignment seems just. Even though assignments are favored, they should not force payment at the full contract price for a contract performed either unsatisfactorily or not at all. For history and analysis of recoupment, see Loyd, The Development of Set-Off, 64 U. of PA. L. REv. 541 (1916); Note, Recoupment-Set-off-and Counterclaim, 28 W. VA. L. Q. 139 (1921).

Most modern codes do not distinguish between recoupment and the other forms of counterclaims. See, e.g., FED. R. Crv. P. 13. But a distinction may still be called for in some situations. For example, Professor Moore suggests using it as the proper basis for segregating compulsory from permissible counterclaims. 3 Moore, Federal Practise 9, n. 1 (1949). Moreover, in tax litigation, the Supreme Court has required a counterclaim to meet recoupment criteria where the Government would have been barred by the statute of limitations from bringing an original action. Stone v. White, 301 U.S. 532 (1937) (recoupment allowed against trustee for amount owed by beneficiary). See Bull v. United States, 295 U.S. 247, 261 (1935). And when the sovereign sues, it is considered to submit to the court's jurisdiction for only "such adverse claims as have arisen out of the same transaction which gave rise to the sovereign's suit. . . . A defendant's right in such regard is one of recoupment." In re Monongahela Rye Liquors, 141 F.2d 864, 869 (3d Cir. 1944). See Note, 50 CoL. L. REv. 505 (1950).

23. Cf. In re Monongahela Rye Liquors, 141 F.2d 864, 869 (3d Cir. 1944) (trustee's claim for the price of liquor sold by the bankrupt to the State Liquor Control Board held not recoupable since "manifestly unrelated" to the State's claim for corporation taxes). See note 5 supra. 